\title{
PENGARUH KOMPETENSI, TIME BUDGET PRESSURE DAN ETIKA AUDITOR TERHADAP KUALITAS AUDIT (Studi Empiris pada Kantor Akuntan Publik di Jakarta Selatan)
}

\author{
Jahormin Simarmata \\ dan \\ Resta Selvia Fatmala \\ Jurusan Akuntansi Fakultas Ekonomi \\ Universitas Satya Negara Indonesia \\ Email: jahormin.simarmata@gmail.com \& resta.sf95@gmail.com
}

\begin{abstract}
The purpose of this research was to determine the effect of competency, time budget pressure, and auditors ethics on audit quality. The population in this research were auditors who worked in Public Accounting Firms of South Jakarta. The number of sample in this research are 80 respondents from 14 Public Accounting Firms. Data on this research were primary data obtained through the spread of questionnaires. The sampling technics that used are purposive sampling method, while the method of processing data that used by the researcher was double regression analysis with the help of SPSS version 21. The results of this hypohesizes research showed that the competency, time budget pressure, and auditor ethics in partial has positive effect and significantly on audit quality and in simultaneously the competency, time budget pressure, and auditor ethics have positive effect and significantly on audit quality by 56,00\%, while the remaining 44,00\% is explained by other variables not include in this research model.
\end{abstract}

Keywords: Competency, Time Budget Pressure, Auditor Ethics and Audit Quality

\begin{abstract}
ABSTRAK
Tujuan penelitian ini adalah untuk mengetahui pengaruh kompetensi, time budget pressure dan etika auditor terhadap kualitas audit. Populasi dalam penelitian ini adalah auditor yang bekerja di beberapa Kantor Akuntan Publik di wilayah Jakarta Selatan. Sampel yang digunakan pada penelitian ini sebanyak 80 responden dari 14 Kantor Akuntan Publik. Data penelitian ini adalah data primer yang diperoleh melalui penyebaran kuesioner. Teknik pengambilan sampel menggunakan metode purposive sample, sedangkan metode pengolahan data yang digunakan peneliti adalah analisis linier berganda dengan bantuan SPSS versi 21. Hasil penelitian ini menunjukkan bahwa kompetensi, time budget pressure dan etika auditor secara parsial berpengaruh positif dan signifikan terhadap kualitas audit dan pengaruh kompetensi, time budget pressure dan etika auditor secara simultan berpengaruh positif dan signifikan tehadap kualitas audit sebesar 56,00\%. Sedangkan sisanya sebesar $44,00 \%$ dijelaskan oleh variabel lain yang tidak termasuk dalam model penelitian ini.
\end{abstract}

Kata Kunci: Kompetensi, Time Budget Pressure, Etika Auditor, dan Kualitas Audit. 


\section{PENDAHULUAN}

Laporan keuangan merupakan catatan informasi keuangan yang dibuat sebagai pertanggungjawaban manajemen perusahaan kepada pihak-pihak yang berkepentingan. Agar laporan keuangan dapat dipercaya keandalan dan kerelevanannya, maka laporan keuangan harus sesuai dengan aturan yang berlaku. Untuk itu perusahaan membutuhkan jasa pihak ketiga yang independen yaitu auditor dalam mengaudit laporan keuangan tersebut. Auditor diharapkan memberikan penilaian atas laporan keuangan yang bebas, tidak memihak, serta mampu menghasilkan laporan keuangan yang benar-benar dapat dipercaya dan berkualitas.

Banyaknya kasus yang menimpa akuntan publik baik di dalam maupun di luar negeri yang terindikasi melakukan kesalahan dalam mengaudit suatu laporan keuangan, sehingga menimbulkan keraguan atas opini audit dan akibatnya masyarakat mempertanyakan kompetensi dan integritas auditor. Seharusnya auditor dalam menjalankan tugasnya wajib berkompeten dalam bidang auditing. Ikatan Akuntan Indonesia (IAI) membuat standar auditing untuk menetapkan kualitas pelaksanaan kerja. Standar itu meliputi standar umum, standar pekerjaan lapangan, dan standar pelaporan. Dalam standar umum tersebut memuat bahwa seorang auditor harus memiliki keahlian dan pelatihan yang cukup sebagai auditor yakni memiliki kompetensi di bidang audit.

De Angelo (1981) dalam Tjun-Tjun Law (2012) mendefinisikan kualitas audit sebagai kemungkinan (joint probability) dimana seorang auditor akan menemukan dan melaporkan pelanggaran yang ada dalam sistem akuntansi kliennya. Kemungkinan dimana auditor akan menemukan salah saji tergantung pada kualitas pemahaman auditor (kompetensi). Lee dan Stone (1995) dalam Elfarini (2007) mendefinisikan kompetensi sebagai keahlian yang cukup yang secara eksplisit dapat digunakan untuk melakukan audit secara obyektif. Kompetensi auditor tersebut didapat dari pelatihan teknis dan nonteknis, dan juga dari pengalaman yang telah dilalui sebelumnya dalam mengaudit laporan keuangan. Maka auditor harus meningkatkan kinerjanya agar dapat menghasilkan suatu laporan audit yang berkualitas dan kompeten bagi pihak-pihak yang berkepentingan. Auditor harus kompeten dalam memahami dan mengetahui sifat usaha klien, jenis dan jumlah bukti yang digunakan dalam proses audit.

Selain harus memiliki kompetensi, ternyata kualitas audit yang dihasilkan juga dipengaruhi oleh time budget pressure (tekanan anggaran waktu) seorang auditor. Persaingan antar Kantor Akuntan Publik (KAP) akan menuntut seorang auditor untuk dapat menggunakan dan memanfaatkan waktu yang telah dianggarkan dengan sebaik mungkin. Apabila sebuah KAP atau auditor tidak tepat waktu dalam memberikan hasil auditannya, maka bisa saja klien akan berpindah dan menggunakan jasa dari KAP atau Auditor lainnya. Sososutikno (2003) dalam Apriyas (2014) mendefinisikan tekanan anggaran waktu adalah keadaan yang menunjukkan auditor dituntut untuk melakukan efisiensi terhadap anggaran waktu yang telah disusun.

Menurut Nirmala (2013), seorang auditor yang seringkali sibuk dengan mengaudit beberapa laporan keuangan perusahaan kadang menghilangkan beberapa atau sebagian prosedur audit untuk mengejar target waktu yang telah ditentukan. Time budget pressure menyebabkan stress individual yang muncul karena adanya ketidakseimbangan tugas dan waktu yang tersedia, serta mempengaruhi etika profesional melalui sikap, nilai, perhatian, dan perilaku auditor (Sososutikno 2003 dalam Apriyas 2014). Maka akibat dari tekanan 
anggaran waktu, auditor cenderung akan bekerja secara cepat sehingga akan berdampak pada penurunan kinerja yang memberikan pengaruh negatif terhadap kualitas audit.

Kualitas audit yang dihasilkan oleh akuntan publik, tidak hanya dipengaruhi oleh kompetensi dan time budget pressure saja, melainkan akuntan publik harus mematuhi kode etik profesi yang mengatur perilaku akuntan publik dalam menjalankan praktik profesinya baik sesama anggota maupun dengan masyarakat umum. Etika profesi akuntan di Indonesia diatur dalam Kode Etik Akuntan Indonesia. Dalam Elfarini (2007) kode etik mengatur tentang tanggung jawab profesi, kompetensi dan kehati-hatian professional, kerahasiaan, perilaku professional serta standar teknis bagi seorang auditor dalam menjalankan profesinya.

Kualitas audit sebagai kemungkinan bahwa auditor akan menemukan dan melaporkan pelanggaran dalam sistem akuntansi klien (Siti Nur Mawar, 2010). Temuan pelanggaran dapat mengukur kualitas audit berkaitan dengan pengetahuan dan keahlian auditor. Pelaporan pelanggaran tergantung kepada dorongan auditor dalam menerapkan kode etik profesinya untuk mengungkapkan pelanggaran tersebut. Kualitas audit yang baik pada prinsipnya dapat dicapai jika auditor menerapkan standar-standar dan prinsip-prinsip audit, bersikap bebas tanpa memihak (independent), patuh kepada hukum serta mentaati segala kode etik profesi (Dessy Kartika, 2015). Maka etika profesi juga salah satu faktor yang dapat mempengaruhi kualitas audit, auditor harus menyadari adanya tanggung jawab yang sangat besar kepada publik, karena sikap dan tindakan etis seorang auditor akan sangat menentukan posisinya dimata masyarakat. Dari uraian tersebut, penelitian ini dilakukan untuk mengetahui kembali pengaruh kompetensi, time budget pressure dan etika auditor terhadap kualitas audit dengan tempat penelitian pada Kantor Akuntan Publik di Wilayah Jakarta Selatan yang bersedia menerima peneliti..

\section{LANDASAN TEORI}

\section{Kualitas Audit}

Tujuan audit umum atas laporan keuangan oleh auditor independen adalah untuk menyatakan pendapat atas kewajaran, dalam semua hal yang material, posisi keuangan, hasil usaha serta arus kas sesuai dengan prinsip akuntansi yang berlaku umum. Profesi akuntan publik sebagai pihak yang independen harus menghasilkan jasa audit yang berkualitas, dimana auditor harus melaksanakan tugas profesionalnya sesuai dengan kode etik dan standar auditing yang telah ditetapkan. Menurut De Angelo (1981) dalam Simanjuntak (2008) menjelaskan definisi kualitas audit adalah gabungan probabilitas seorang auditor untuk dapat menemukan dan melaporkan penyelewengan yang terjadi dalam sistem akuntansi klien. Seorang auditor dituntut untuk dapat menghasilkan kualitas pekerjaan yang tinggi, karena auditor mempunyai tanggung jawab yang besar terhadap pihak-pihak yang berkepentingan terhadap laporan keuangan suatu perusahaan termasuk masyarakat, tidak saja hanya bergantung pada klien saja. 
Deis and Groux dalam Rr. Putri Arsika Nirmala (2013:14) melakukan penelitian tentang empat hal yang dianggap memiliki hubungan dengan kualitas audit, yaitu :

1. Lama waktu auditor melakukan pemeriksaan terhadap suatu perusahaan. Semakin lama seorang auditor telah melakukan audit pada klien yang sama, maka akan menghasilkan kualitas audit yang semakin rendah.

2. Jumlah klien. Semakin banyak jumlah klien maka kualitas audit akan semakin baik karena auditor akan berusaha menjaga reputasinya. Auditor yang telah berpengalaman tentu akan menjaga reputasinya untuk menghasilkan opini audit yang berkualitas agar klien tidak memilih KAP lain dalam mengaudit laporan keuangannya.

3. Kesehatan keuangan klien. Semakin sehat kondisi keuangan klien maka ada kecenderungan klien tersebut menekan auditor agar tidak mengikuti standar yang berlaku.

4. Review oleh pihak ketiga. Kualitas audit akan meningkat jika auditor mengetahui bahwa hasil pekerjaannya akan di-review oleh pihak ketiga karena seorang auditor akan berusaha menjaga reputasinya dengan menghasilkan laporan audit yang berkualitas.

\section{Kompetensi Auditor}

Dalam pelaksanaan audit dan penyusunan laporannya, auditor wajib menggunakan kemahiran profesionalitasnya dengan cermat dan seksama. Oleh karena itu, kemahiran sangat diperlukan oleh seorang auditor dalam melaksanakan tugasnya sebagai seorang auditor (SA seksi 230 dalam SPAP 2011). Kompetensi menunjukan terdapatnya pencapaian dan pemeliharaan suatu tingkatan pemahaman dan pengetahuan yang memungkinkan seseorang anggota untuk memberikan jasa dengan kemudahan dan kecerdikan (Mulyadi,2013:19).

Hasil penelitian yang dilakukan oleh Purwanti dkk (2007) menunjukkan bahwa komponen kompetensi untuk auditor di Indonesia terdiri atas :

a. Pengetahuan

Komponen pengetahuan, yang merupakan komponen penting dalam suatu kompetensi. Komponen ini meliputi pengetahuan terhadap fakta-fakta, prosedur-prosedur dan pengalaman.

b. Komunikasi

Ciri-ciri psikologi, seperti kemampuan berkomunikasi, kreativitas, kemampuan bekerja sama dengan orang lain.

\section{Time Budget Pressure}

Sososutikno (2003) dalam Tri Maya Apriyas (2014:24) mendefinisikan tekanan anggaran waktu adalah keadaan yang menunjukkan auditor dituntut untuk melakukan efisiensi terhadap anggaran waktu yang telah disusun. Nataline (2007) juga menyebutkan bahwa saat menghadapi tekanan anggaran waktu, auditor akan memberikan respon dengan dua cara yaitu, fungsional dan disfungsional. Tipe fungsional adalah perilaku auditor untuk bekerja lebih baik dan menggunakan waktu sebaik-baiknya. Sedangkan, tipe disfungsional adalah perilaku auditor yang membuat penurunan kualitas audit (Setyorini, 2011:15). 
Alokasi waktu yang lama dari auditor dalam mengaudit laporan keuangan klien akan menimbulkan biaya audit yang besar sehingga klien akan menanggung fee audit yang besar pula. Klien menjadi tidak percaya bahwa auditor tersebut dapat menyelesaikan tugasnya tepat waktu sehingga klien lebih memilih KAP lain dalam mengaudit laporan keuangannya (Apriyas, 2014: 23).

Fungsi anggaran waktu dalam Kantor Akuntan Publik adalah sebagai dasar estimasi biaya audit, alokasi staf ke masing-masing pekerjaan dan evaluasi kinerja staf auditor dari atasan. Anggaran waktu yang telah dibuat oleh auditor bertujuan untuk mengurangi biaya audit serta meningkatkan efektivitas audit (Waggoner dan Cashell, 1991 dalam Sastra, 2011). Tekanan anggaran waktu audit sebenarnya merupakan situasi normal yang ada dalam lingkungan pekerjaan auditor (Basuki dan Mahardani, 2006). Maka dari itu dibutuhkan perencanaan audit secara maksimal termasuk penilaian risiko, estimasi waktu audit, maupun alokasi staf audit.

\section{Etika Auditor}

Menurut Sukrisno Agoes (2009: 26) menjelaskan bahwa Etika berasal dari kata Yunani "ethos" (bentuk tunggal) yang berarti: tempat tinggal, padang rumput, kandang, kebiasaan, adat, watak, perasaan, sikap, cara berpikir. Bentuk jamaknya adalah ta-etha, yang berarti adat istiadat. Dalam hal ini, kata etika sama pengertiannya dengan moral. Moral berasal dari kata Latin: mos (bentuk tunggal), atau mores (bentuk jamak) yang berarti adat istiadat, kebiasaan, kelakukan, watak, tabiat, akhlak, cara hidup). Menurut Rendy, Jullie, Ventje (2013), Etika Profesi Auditor adalah sebuah profesi harus memiliki komitmen moral yang tinggi dalam bentuk aturan khusus. Aturan ini merupakan aturan main dalam menjalankan atau mengemban profesi tersebut, yang biasa disebut kode etik. Ida Suraida (2005) dalam Dessy Kartika (2015:30), menyatakan bahwa Etika auditor akan dipengaruhi oleh kesadaran etis dan kepedulian pada etika profesi, yaitu kepedulian pada Kode Etik IAI yang merupakan panduan dan aturan bagi seluruh anggota dalam memenuhi tanggung jawab profesionalnya. Kode Etik Profesi Akuntan Publik adalah pedoman bagi para anggota institut Akuntan Publik Indonesia untuk bertugas secara bertanggung jawab dan obyektif (Sukrisno, 2016: 42). Prinsip etika profesi yang merupakan landasan perilaku etika professional, terdiri atas 8 prinsip yaitu: tanggung jawab profesi, kepentingan publik, integritas, obyektif, kompetensi dan kehati-hatian profesional, kerahasiaan, prilaku professional, dan standar teknis.

\section{Jenis Data}

\section{METODE PENELITIAN}

Dalam penelitian ini peneliti menggunakan data primer untuk mengukur variabel independen (Kompetensi Auditor, Time budget Pressure dan Etika Auditor) serta variabel dependen (Kualitas Audit) yang diambil melalui sebaran kuesioner dari individu atau perseorangan auditor. 


\section{Populasi dan Sampel}

Dalam penelitian ini, populasinya adalah auditor yang bekerja di beberapa Kantor Akuntan Publik di Wilayah Jakarta Selatan. Sedangkan untuk sampel ada sebanyak 80 responden dari 14 Kantor Akuntan Publik. Teknik pengambilan sampel yaitu Purposive Sampling berdasarkan kriteria tertentu yang ditetapkan peneliti secara obyektif.

\section{Metode Analisis Data dan Hipotesis}

Skala pengukuran yang digunakan dengan merubah skala ordinal ke interval dengan tipe skala Likert lima (5) poin dengan rentang angka 1-5 yang memberikan gambaran sampai seberapa jauh responden melaksanakan fungsi sesuai dengan pernyataan yang diberikan. Metode statitika yang digunkan dalam menguji hipotesis dalam penelitian ini adalah dengan Regresi Liniear Berganda dengan menggunakan program Statistik Program Social Science (SPSS) versi 21.0. Sebelum menganalisi data akan diuji validitas dan reliabilitas serta uji asumsi klasik

\section{HASIL DAN PEMBAHASAN}

\section{Uji Pendahuluan}

\section{a. Uji Validitas}

Menurut Ghozali (2016), suatu variabel dikatakan valid apabila nilai $r_{\text {hitung }}>r_{\text {tabel }}$ Nilai $\mathrm{t}_{\text {tabel }}$ diperoleh melalui rumus df (degree of freedom $)=\mathrm{n}-\mathrm{k}-1$ dimana $\mathrm{n}$ adalah jumlah responden dan k merupakan jumlah content (variabel independen), sedangkan 1 merupakan uji satu sisi sehingga $r$ table adalah 0,233 dengan taraf signifikansi $\alpha=5 \%$. Tabel 1.1 berikut menunjukkan hasil uji validitas.

Tabel. 1.1

\begin{tabular}{|c|r|c|}
\hline $\begin{array}{c}\text { Variabel } \\
\text { Penelitian }\end{array}$ & $\begin{array}{c}\text { Corrected Item- } \\
\text { Total } \\
\text { Correlation }\end{array}$ & $\begin{array}{c}\text { Total } \\
\text { Ques } \\
\text { tioner }\end{array}$ \\
\hline $\begin{array}{c}\text { Kompetensi } \\
\text { (X1) }\end{array}$ & $\begin{array}{r}0,627 \mathrm{~s} / \mathrm{d} \\
0,789\end{array}$ & 7 \\
Time Budget & $0,367 \mathrm{~s} / \mathrm{d}$ & 8 \\
Pressure (X2) \\
$\begin{array}{r}0,786 \\
\text { Etika Auditor } \\
\text { (X3 }\end{array}$ & $\begin{array}{r}0,639 \mathrm{~s} / \mathrm{d} \\
0,841\end{array}$ & 8 \\
$\begin{array}{c}\text { Kualitas Audit } \\
\text { (Y) }\end{array}$ & $\begin{array}{r}0,304 \mathrm{~s} / \mathrm{d} \\
0,680\end{array}$ & 6 \\
\hline
\end{tabular}


Dari hasil table 1.1 di atas uji validitas tersebut diketahui bahwa r-hitung lebih besar dari r-tabel 0,233, sehingga semua variable yang diuji adalah valid.

\section{b. Uji Reliabilitas}

Uji reliabilitas digunakan untuk menunjukkan ukuran kestabilan dan konsistensi dari konsep ukuran instrumen atau alat ukur, sehingga nilai yang diukur tidak berubah dalam nilai tertentu. Suatu variabel dikatakan reliabel apabila memberikan nilai Cronbach's Alpha $\geq 0,70$. Tabel 1.2 berikut, menunjukkan hasil uji reliabilitas.

Tabel 1.2

\begin{tabular}{|c|c|c|}
\hline $\begin{array}{c}\text { Variabel } \\
\text { Penelitian }\end{array}$ & $\begin{array}{c}\text { Cronbach's } \\
\text { Alpha }\end{array}$ & N of Items \\
\hline $\begin{array}{c}\text { Kompetensi } \\
\text { (X1) }\end{array}$ & 0,902 & 7 \\
$\begin{array}{c}\text { Time Budget } \\
\text { Pressure (X2) } \\
\text { Etika Auditor } \\
\text { (X3 }\end{array}$ & 0,862 & 8 \\
$\begin{array}{c}\text { Kualitas Audit } \\
\text { (Y) }\end{array}$ & 0,941 & 8 \\
\hline
\end{tabular}

Dari hasil uji reliabilitas diketahui bahwa Cronbach's Alpha lebih besar dari 0,70 , sehingga semua variable yang diuji dinyatakan reliable.

\section{Uji Asumsi Klasik}

\section{a. Uji Normalitas}

Uji Normalitas bertujuan untuk menguji apakah dalam model regresi, variabel bebas dan terikat memiliki distribusi normal dan mengetahui distribusi data dalam suatu variabel yang akan digunakan dalam sebuah penelitian apakah data layak atau tidak dianalisis. Model regresi yang baik adalah memiliki distribusi data normal. Dalam penelitian ini Normalitas dapat diketahui dengan melihat tabel One-Sample Kolmogorov - Smirnov Test pada kolom Asymp, Sig (2-tailed) yaitu data dikatakan berdistribusi normal apabila $p$ value (sig) > 0,05. Tabel 2.1 berikut menunjukkan hasil uji normalitas. 
Tabel 2.1

One-Sample Kolmogorov-Smirnov Test

\begin{tabular}{|c|c|c|c|c|}
\hline & $\mathrm{X} 1$ & $\mathrm{X} 2$ & $\mathrm{X} 3$ & $\mathrm{Y}$ \\
\hline $\mathrm{N}$ & 80 & 80 & 80 & 80 \\
$\begin{array}{c}\text { Kolmogorov- } \\
\text { Smirnov Z } \\
\text { Asymp. Sig. (2- } \\
\text { tailed) }\end{array}$ & 1,088 & 1,165 &, 942 & 1,111 \\
\hline
\end{tabular}

a. Test distribution is Normal.

b. Calculated from data.

Dari hasil uji normalitas tersebut diketahui bahwa Sample Kolmogorov Smirnov Test pada kolom Asymp, Sig (2-tailed) atau $p$ value (sig) > 0,05, sehingga semua variable yang diuji dinyatakan terdistribusi normal.

\section{b. Uji Multikolonieritas}

Uji multikolinieritas bertujuan untuk menguji apakah model regresi ditemukan adanya korelasi antar variabel bebas (independen). Model regresi yang baik seharusnya tidak terjadi korelasi diantara variabel bebas. Untuk mengetahui apakah suatu model regresi bebas dari multikoleniaritas yaitu dapat dilakukan dengan melihat nilai Tolerance $>0,10$ atau sama dengan nilai VIF $<10$. Tabel 2.2 berikut menunjukkan hasil uji multikoleniaritas.

Tabel 2.2

\begin{tabular}{|c|c|c|}
\hline Model & \multicolumn{2}{|c|}{$\begin{array}{c}\text { Collinearity Statistics } \\
\text { Tolerance }\end{array}$} \\
\hline VIF \\
\hline Constant) & & \\
Kompetensi (X1 &, 647 & 1,547 \\
Time Budget &, 612 & 1,633 \\
Pressure (X2) & & \\
Etika Auditor (X3 &, 934 & 1,070 \\
\hline
\end{tabular}

Berdasarkan hasil output SPSS tersebut menunjukan besarnya nilai Tolerance dan Variant Inflation Factor (VIF) untuk masing-masing Variabel Independen yaitu nilai tolerance $>0,10$ dan nilai VIF $<10$ sehingga dapat disimpulkan bahwa antar variabel independen tidak terjadi multikolinieritas.

\section{c. Uji Heteroksidastisitas}

Menurut Ghozali (2016:139), Uji Heteroksidastisitas bertujuan menguji apakah dalam model regresi terjadi ketidaksamaan variance dari residual satu pengamatan ke pengamatan lain Model regresi yang baik adalah yang Homoskedastisitas atau tidak terjadi heteroksidastisitas. Deteksi ada atau tidaknya heteroskedastisitas dapat dilihat dengan ada tidaknya pola tertentu pada grafik Scatterplot. Jika ada pola tertentu maka 
mengidentifikasikan telah terjadi heteroskedastisitas. Tetapi jika tidak ada pola yang jelas serta titik-titik menyebar diatas dan dibawah angka 0 pada sumbu Y, maka tidak terjadi heteroskesdastisitas. Gambar berikut menunjukkan hasil ujinya,

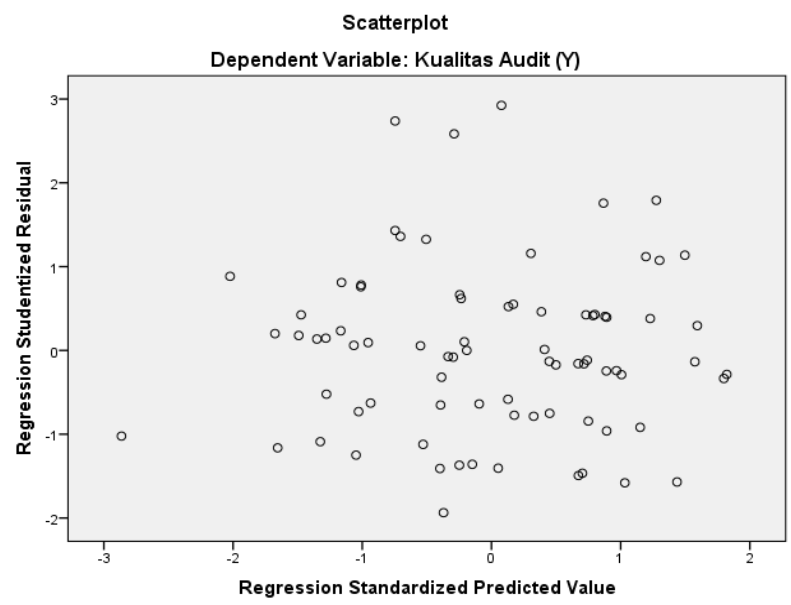

Grafik Scatterplot di atas menunjukan bahwa data tersebar diatas dan dibawah angka 0 (nol) pada sumbu Y dan tidak terdapat suatu pola yang jelas pada penyebaran data tersebut. Hal ini berarti tidak terjadi heteroskedastisitas pada model persamaan Regresi, sehingga model regresi layak digunakan memprediksi kualitas audit berdasarkan variable independen kompetensi, time budget pressure dan etika auditor

\section{d. Uji Auto Korelasi}

Uji auto korelasi bertujuan menguji apakah dalam model regresi linier ada korelasi antara kesalahan pengganggu pada periode $t$ dengan kesalahan pengganggu pada periode $t-1$ (sebelumnya). Jika terjadi korelasi, maka dinamakan ada problem autokorelasi. Autokorelasi muncul karena observasi yang berurutan sepanjang waktu berkaitan satu sama lainnya. Model regresi yang baik adalah regresi yang bebas dari autokorelasi. Ada beberapa cara yang dapat digunakan untuk mendeteksi ada atau tidaknya autokorelasi. Metode pengujian yang sering digunakan adalah dengan uji Durbin-Watson (DW-test) dengan ketentuan sebagai berikut (Imam Ghozali, 2016 : 9596) :

\begin{tabular}{|c|c|c|}
\hline Hipotesis Nol & Keputusan & Jika \\
\hline $\begin{array}{c}\text { Tidak ada } \\
\text { autokorelasi } \\
\text { positif }\end{array}$ & Tolak & $0<\mathrm{d}<\mathrm{dl}$ \\
\hline $\begin{array}{c}\text { Tidak ada } \\
\text { autokorelasi } \\
\text { positif }\end{array}$ & $\begin{array}{c}\text { No } \\
\text { desicison }\end{array}$ & $\mathrm{dl} \leq \mathrm{d} \geq \mathrm{du}$ \\
\hline $\begin{array}{c}\text { Tidak ada } \\
\text { korelasi negative }\end{array}$ & Tolak & $4-\mathrm{dl}<\mathrm{d}<$ \\
\hline $\begin{array}{c}\text { Tidak ada } \\
\text { korelasi negative }\end{array}$ & $\begin{array}{c}\text { No } \\
\text { desicison }\end{array}$ & $\begin{array}{c}4-\mathrm{du} \leq \mathrm{d} \leq \\
4-\mathrm{dl}\end{array}$ \\
\hline $\begin{array}{c}\text { Tidak ada } \\
\text { autokorelasi, } \\
\text { positif atau } \\
\text { negative }\end{array}$ & Tidak & $\mathrm{du}<\mathrm{d}<4-$ \\
$\mathrm{du}$
\end{tabular}


Berdasarkan tabel statistik Durbin Watson di atas, dengan signifikansi 0,05 dan jumlah data $(\mathrm{n})=80$, serta $\mathrm{k}=3(\mathrm{k})$ adalah jumlah variabel independen) diperoleh nilai dL sebesar 1,560 dan dU sebesar 1,715. Untuk mengetahui apakah terdapat autokorelasi dalam model regresi dapat dilihat pada Model Summary tabel 2.3 sebagai berikut :

\begin{tabular}{|c|c|c|c|c|c|}
\hline Model & $\mathrm{R}$ & $\begin{array}{c}\mathrm{R} \\
\text { Square }\end{array}$ & $\begin{array}{c}\text { Adjust } \\
\text { ed R } \\
\text { Square }\end{array}$ & $\begin{array}{c}\text { Std. Error } \\
\text { of the } \\
\text { Estimate }\end{array}$ & $\begin{array}{c}\text { Durbin- } \\
\text { Watson }\end{array}$ \\
\hline 1 &, $760^{\mathrm{a}}$ &, 577 &, 560 & 1,65436 & 2,133 \\
\hline
\end{tabular}
a. Predictors: (Constant), Etika Auditor (X3),
Time Budget Pressure (X2), Kompetensi (X1),
b. Dependent Variable: Kualitas Audit (Y)

Dari tabel 2.3 Model Summary ${ }^{b}$ didapat nilai DW yang dihasilkan dari model regresi adalah 2,133 lebih besar dari batas (dU) 1,715 dan kurang dari 2,285 (4 - dU), maka dapat disimpulkan bahwa tidak ada autokorelesi positif atau negatif atau dapat disimpulkan tidak terdapat autokorelasi.

\section{Analisis Regressi Linier Berganda}

Dengan menggunakan SPSS dapat diperoleh tabel 3.1 hasil koefisien regresi sebagai berikut ini :

\begin{tabular}{|c|c|c|c|c|c|c|c|}
\hline \multirow[t]{2}{*}{ Model } & \multicolumn{2}{|c|}{$\begin{array}{l}\text { Unstanda } \\
\text { rdized } \\
\text { Coefficie } \\
\text { nts }\end{array}$} & \multirow{2}{*}{$\begin{array}{c}\text { Stan } \\
\text { dard } \\
\text { ized } \\
\text { Coe } \\
\text { ffici } \\
\text { ents } \\
\text { Bet } \\
\text { a }\end{array}$} & \multirow[t]{2}{*}{$\mathrm{T}$} & \multirow[t]{2}{*}{ Sig. } & \multicolumn{2}{|c|}{$\begin{array}{c}\text { Collineari } \\
\text { ty } \\
\text { Statistics }\end{array}$} \\
\hline & B & $\begin{array}{l}\text { Std. } \\
\text { Erro } \\
\text { r }\end{array}$ & & & & $\begin{array}{c}\text { Tol } \\
\text { eran } \\
\text { ce }\end{array}$ & VIF \\
\hline $\begin{array}{l}\text { (Consta } \\
\text { nt) }\end{array}$ & $\begin{array}{r}3,7 \\
69\end{array}$ & $\begin{array}{r}2,35 \\
4\end{array}$ & & $\begin{array}{r}1,60 \\
1\end{array}$ &, 114 & & \\
\hline $\begin{array}{c}\text { Kompete } \\
\text { nsi (X1) } \\
\text { Time }\end{array}$ & $\begin{array}{r}, 26 \\
9\end{array}$ & ,075 & ,331 & $\begin{array}{r}3,56 \\
7\end{array}$ & ,001 & ,647 & $\begin{array}{r}1,5 \\
47\end{array}$ \\
\hline Budget & ,28 & .062 & .431 & 4,52 & .000 & .612 & 1,6 \\
\hline $\begin{array}{c}\text { Pressure } \\
\text { (X2) }\end{array}$ & 2 &, 002 & 1 & 3 &, 000 &, 012 & 33 \\
\hline $\begin{array}{c}\text { Etika } \\
\text { Auditor } \\
\text { (X3) }\end{array}$ & $\begin{array}{r}17 \\
2\end{array}$ & ,059 & ,226 & $\begin{array}{r}2,93 \\
2\end{array}$ & ,004 & ,934 & $\begin{array}{r}1,0 \\
70\end{array}$ \\
\hline
\end{tabular}

a. Dependent Variable: Kualitas Audit (Y) 
Berdasarkan table 3.1 yang telah diperoleh dari koefisien regresi di atas, maka dapat dibuat suatu persamaan regresi linear berganda sebagai berikut :

$$
\mathrm{Y}: 3,769+0,269 x_{1}+0,282 x_{2}+0,172 x_{3}+\varepsilon
$$

Persamaan regressi linier tersebut dapat diuraikan sbb :

1. Nilai Konstanta sebesar 3,769 artinya jika variabel Kompetensi (X1), Time Budget Pressure (X2), Etika Auditor (X3) memiliki nilai sebesar 0 maka variabel Kualitas Audit (Y) akan memiliki nilai sebesar 3,769.

2. Koefisien regresi variabel Kompetensi (X1) sebesar 0,269 artinya jika kompetensi mengalami kenaikan 1 (satu) satuan, maka akan menaikkan kualitas audit sebesar 0,269 atau 26,9\%.

3. Koefisien regresi variabel Time Budget Pressure (X2) sebesar 0,282 artinya jika time budget pressure mengalami kenaikan 1 (satu) satuan, maka akan menaikkan kualitas audit sebesar 0,282 atau 28,2\%.

4. Koefisien regresi variabel Etika Auditor (X3) sebesar 0,172 artinya jika etika auditor mengalami kenaikan 1 (satu) satuan, maka akan menaikkan kualitas audit sebesar 0,172 atau $17,2 \%$.

\section{Hipothesis}

\section{Uji Parsial ( Uji - t )}

Uji t yaitu suatu uji untuk mengetahui signifikansi pengaruh variabel bebas (Kompetensi, Time Budget Pressure dan Etika Auditor) secara parsial atau individual menerangkan terhadap variabel terikat (Kualitas Audit). Pengujian ini dinilai dengan taraf signifikansi $\alpha=5 \%$. Selanjutnya untuk mengetahui signifikan pengaruh atau hubungan antara variabel dilakukan dengan kriteria pengujian "jika Sig $<0.05$, maka Ho ditolak dan Ha diterima atau sebaliknya". Menentukan nilai $t_{\text {tabel }}$ juga dapat ditentukan dengan tingkat signifikasi 5\% dengan derajat kebebasan df $=(\mathrm{n}-\mathrm{k}-1)$ dimana $\mathrm{n}$ adalah jumlah responden dan $\mathrm{k}$ adalah jumlah variabel. $\mathrm{T}$ tabel dapat dilihat pada tabel statistik pada signifikansi 0.05 dengan derajat kebebasan $(\mathrm{df})=\mathrm{n}-\mathrm{k}-1=80-3-1=76$. Hasil yang diperoleh untuk $\mathbf{t}_{\text {tabel }}$ sebesar 1.991, Kriteria pengujian yang digunakan adalah jika $t_{\text {hitung }}>t_{\text {tabel }}(n-k-1)$ maka Ho ditolak dan Ha diterima atau sebaliknya.

Berdasarkan tabel 3.1 yang telah diperoleh dari koefisien regresi di atas, maka dapat hasil uji parsial(uji t) sebagai berikut :

\section{a. Kompetensi Audit (X1) Berpengaruh Secara Positif dan Signifikan Terhadap Kualitas Audit}

Hasil pengujian statistik menunjukkan bahwa kompetensi mempunyai nilai $t_{\text {hitung }}$ sebesar 3,567 dimana $t_{\text {hitung }}$ bernilai lebih besar dari $t_{\text {tabel }}$ sebesar 1,991 (3,567 $>1,991$ ) dan tingkat signifikan sebesar 0,001 . Hal ini dapat dinyatakan bahwa Ho ditolak dan Ha diterima, artinya bahwa kompetensi berpengaruh secara positif dan signifikan terhadap kualitas audit sebesar $26,9 \%$. Penerapan pengetahuan yang maksimal tentunya akan sejalan dengan semakin bertambahnya keahlian yang dimiliki, sehingga mampu menghasilkan kualitas audit yang baik. Kondisi ini 
menunjukkan bahwa semakin baik kompeten seorang auditor maka semakin baik pula kualitas audit yang dihasilkan oleh auditor tersebut.

b. Time Budget Pressure (X2) Berpengaruh Secara Positif dan Signifikan Terhadap Kualitas Audit

Hasil pengujian statistik menunjukkan bahwa Time Budget Pressure mempunyai nilai $t_{\text {hitung }}$ sebesar 4,523 dimana $t_{\text {hitung }}$ bernilai lebih besar dari $t_{\text {tabel }}$ sebesar 1,991 $(4,523>1,991)$ dan tingkat signifikan sebesar 0,000 . Hal ini dapat dinyatakan bahwa Ho ditolak dan Ha diterima, artinya bahwa Time Budget Pressure berpengaruh secara positif dan signifikan terhadap kualitas audit sebesar 28,2\%. Time budget pressure dapat mempengaruhi kinerja seorang auditor dalam pengambilan keputusan dan pelaksanaan prosedur audit, antara lain auditor terpacu untuk dapat menyelesaikan pekerjaan dan tanggungjawabnya tepat pada waktunya. Kondisi ini menunjukkan bahwa semakin baik time budget pressure yang dimiliki oleh seorang auditor maka semakin baik pula kualitas audit yang dihasilkan oleh auditor tersebut.

\section{c. Etika Auditor (X3) Berpengaruh Secara Positif dan Signifikan Terhadap Kualitas Audit}

Hasil pengujian statistik menunjukkan bahwa Etika Auditor mempunyai nilai $t_{\text {hitung }}$ sebesar 2,932 dimana $t_{\text {hitung }}$ bernilai lebih besar dari $t_{\text {tabel }}$ sebesar 1,991 (2,932 > 1,991) dan tingkat signifikan sebesar 0,004. Hal ini dapat dinyatakan bahwa Ho ditolak dan Ha diterima, artinya bahwa Etika Auditor berpengaruh secara positif dan signifikan terhadap kualitas audit sebesar $17,2 \%$. Sebagai seorang auditor yang memiliki kesadaran untuk selalu berperilaku secara etis berarti memiliki komitmen untuk menerapkan Kode Etik Profesi Akuntan Publik. Kondisi ini menunjukkan bahwa semakin baik etika yang dimiliki oleh seorang auditor maka semakin baik pula kualitas audit yang dihasilkan oleh auditor tersebut.

\section{Uji Simultan ( Uji - F )}

\section{Kompetensi (X1), Time Budget Pressure (X2) dan Etika Auditor (X3) Secara Simultan Berpengaruh Positif Dan Signifikan Terhadap Kualitas Audit (Y)}

Uji F ini digunakan untuk mengetahui ada tidaknya pengaruh secara bersamasama (simultan) variabel independen (bebas) terhadap variabel dependen (terikat). Pembuktian dilakukan dengan cara membandingkan nilai $F_{\text {hitung }}$ dengan $F_{\text {tabel }}$ pada tingkat kepercayaan 5\% dan derajat kebebasan (degree of freedom) $\mathrm{df}=(\mathrm{n}-\mathrm{k}-1)$ dimana $\mathrm{n}$ adalah jumlah responden dan $\mathrm{k}$ adalah jumlah variable, sehingga $F$ table dalam pengujian ini diperoleh sebesar 2,72. Kriteria pengujian yang digunakan yaitu jika $F_{\text {hitung }}$ $>\mathrm{F}_{\text {tabel }}(\mathrm{n}-\mathrm{k}-1)$ maka Ho ditolak, Ha diterimadan sebaliknya. Selain itu uji F dapat pula dilihat dari besarnya probabilitas value ( $p$ value) dibandingkan dengan 0,05 (Taraf signifikansi $\alpha=5 \%$ ). Adapun kriteria pengujian yang digunakan yaitu jika $\mathrm{p}$ value < 0,05 maka Ho ditolak, Ha diterima dan sebaliknya. 
Hasil uji F dapat dilihat pada table 3.2 berikut ini :

\begin{tabular}{|l|c|r|r|c|c|}
\hline Model & $\begin{array}{c}\text { Sum of } \\
\text { Squares }\end{array}$ & Df & $\begin{array}{c}\text { Mean } \\
\text { Squar } \\
\text { e }\end{array}$ & F & Sig. \\
\hline Regressio & 283,945 & 3 & $\begin{array}{r}94,64 \\
8\end{array}$ & $\begin{array}{r}34,58 \\
\mathrm{n}\end{array}$ & $\begin{array}{r}000 \\
\mathrm{~b}\end{array}$ \\
Residual & 208,005 & 76 & 2,737 & & \\
Total & 491,950 & 79 & & & \\
\hline
\end{tabular}

a. Dependent Variable: Kualitas Audit (Y)

b. Predictors: (Constant), Etika Auditor (X3), Time

Budget Pressure (X2), Kompetensi (X1)

Hasil pengujian statistic pada table 3.2 menunjukkan $\mathrm{F}_{\text {hitung }}$ sebesar 34,582 dimana $F_{\text {hitung }}$ bernilai lebih besar dari $\mathrm{F}_{\text {tabel }}(34,582>2,72)$. Hasil uji empiris diperoleh nilai $F$ hitung sebesar 34,582 dengan nilai signifikan sebesar 0,000 yang memiliki nilai lebih kecil dari tingkat signifikan sebesar 0,05 $(0,000<0,05)$. Maka dapat diambil keputusan untuk menolak Ho dan Ha diterima. Sehingga dapat disimpulkan bahwa Kompetensi, Time Budget Pressure, dan Etika Auditor secara simultan berpengaruh positif dan signifikan terhadap kualitas audit. Diperoleh pada Model Summary table 2.3, nilai koefisien determinasi (adjusted $\mathrm{R}^{2}$ ) sebesar 0,560. Ini menunjukkan bahwa sebesar $56,00 \%$ variabel kompetensi, time budget pressure, etika auditor memiliki pengaruh yang cukup terhadap kualitas audit. Artinya kualitas audit yang dihasilkan auditor tidak terlepas dari kompetensi, time budget pressure dan etika auditor yang baik untuk dapat melaksanakan dan menyelesaikan pekerjaan auditnya dengan baik. Sedangkan sisanya sebesar 44,00\% dijelaskan oleh variabel lain yang tidak diteliti dalam penelitian ini.

\section{Kesimpulan}

\section{KESIMPULAN DAN SARAN}

Berdasarkan hasil penelitian ini mengenai "Pengaruh Kompetensi, Time Budget Pressure dan Etika Auditor terhadap Kualitas Audit " yang dikumpulkan pada KAP di daerah Jakarta Selatan, maka dapat ditarik kesimpulan sebagai berikut :

1. Kompetensi berpengaruh positif dan signifikan terhadap kualitas audit sebesar $26,9 \%$ dengan tingkat signifikansi 0,001. Artinya semakin baik kompetensi seorang auditor maka semakin baik kualitas audit yang dihasilkan auditor tersebut.

2. Time Budget Pressure berpengaruh positif dan signifikan terhadap kualitas audit sebesar 28,2\% dengan tingkat signifikansi 0,000. Artinya semakin baik time budget pressure yang dimiliki oleh seorang auditor maka semakin baik pula kualitas audit yang dihasilkan oleh auditor tersebut.

3. Etika Auditor berpengaruh positif dan signifikan terhadap kualitas audit sebesar 17,2\% dengan tingkat signifikansi 0,004. Artinya semakin baik etika yang dimiliki oleh seorang auditor maka semakin baik pula kualitas audit yang dihasilkan oleh auditor tersebut. 
4. Hasil penelitian ini menunjukan bahwa kompetensi, time budget pressure dan etika auditor secara bersama-sama memiliki pengaruh positif dan signifikan terhadap kualitas audit sebesar 56\% dengan tingkat signifikansi 0,000. Artinya kompetensi, time budget pressure, dan etika auditor secara bersama-sama memiliki pengaruh yang cukup signifikan sebesar 56,00\% terhadap kualitas audit, sedangkan sisanya sebesar $44,00 \%$ dipengaruhi oleh faktor-faktor lain di luar model penelitian ini seperti pengalaman, independensi, fee audit, perbedaan gender, persaingan bisnis, kompleksitas tugas, dll..

\section{Saran}

Harapan peneliti pada penelitian selanjutnya yaitu dapat memperbaiki kekurangankekurangan penelitian ini diantaranya:

1. Sebaiknya penyebaran kuesioner tidak dilakukan di bulan sibuk (desember-februari), karena waktu tersebut kurang efektif, dimana waktu tersebut kesibukan auditor cukup tinggi. Dengan demikian, kuesioner atau angket yang disebarkan kurang mendapat tanggapan yang baik.

2. Melakukan penelitian dalam lingkup yang lebih luas dan waktu yang cukup sehingga dapat diperoleh data dan hasil analisa yang lebih akurat.

3. Menggunakan alat uji yang lebih baik lagi agar menghasilkan data yang akurat.

4. Melanjutkan dan mengulang kembali penelitian tentang pengaruh kompetensi, time budget pressure dan etika auditor agar dapat diperoleh bukti empiris tambahan apakah ketiga variabel tersebut mempunyai korelasi yang saling mempengaruhi.

5. Mengembangkan penelitian dengan menambahkan faktor-faktor dan variabel lain diluar model penelitian ini. 


\section{DAFTAR PUSTAKA}

\section{Buku - Buku :}

Agoes, S. (2009). Etika Bisnis dan Profesi Tantangan Membangun Manusia Seutuhnya. Jakarta: Salemba Empat.

Agoes, S. (2016). Auditing : Petunjuk Praktis Pemeriksaan Akuntan Oleh Kantor Akuntan Publik. Jakarta: Salemba Empat.

Arens, A. A., Beasley, M. S., \& Elder, R. J. (2010). Auditing dan Jasa Asuransi. Jakarta: Salemba Empat

Arens, A. A., Beasley, M. S., Elder, R. J., \& Jusuf, A. A. (2012). Jasa Auditan dan Asurance. Jakarta: Salemba Empat.

Ghozali, I. (2016). Aplikasi Analisis Multivariate dengan Program IBM SPSS 23 Edisi VIII. Semarang: Universitas Dioponogoro.

Halim, A. (2008). Auditin I (Dasar-Dasar, Edisi Ketiga Audit Laporan Keuangan). Yogyakarta: UPP AMP YKPN.

IAPI. (2011). Standar Profesional Akuntan Publik. Jakarta: Salemba Empat

Ludigdo, U. (2007). Paradoks Etika Akuntan. Yogyakarta: Pustaka Pelajar.

Mulyadi. (2013). Sistem Akuntansi. Jakarta : Salemba Empat.

Riduan, \& Kuncoro, E. A. (2007). cara Menggunakan dan Memaknai Analisis Jalur (Path Analysis). Bandung: Alpabeta.

Soewadji, J. (2012). Pengantar Metodelogi Penelitian. Jakarta: Wacana Medika.

Sudarmanto. (2009). Kinerja dan Pengembangan Kompetensi SDM. Yogyakarta: Pustaka Pelajar .

Sugiyono. (2015). Metode Penelitian Kuantitatif, Kualitatif dan R\&D. bandung: Alfabeta.

Undang-Undang Republik Indonesia Nomor 5 Tahun 2011 Tentang Akuntan Publik.

\section{Jurnal - Jurnal :}

Alim, M. N., Hapsani, T., \& Purwanti, L. (2007). Pengaruh Kompetensi dan Independensi Terhadap Kualitas Audit dengan Etika Auditor sebagai Variabel Moderasi.

Apriyas, T. M. (2014). Pengaruh Kompetensi, Indenpendensi, dan Time Budget Pressure bagi Auditor Terhadap Kualitas Audit.

Arisinta, O. (2013). Pengaruh Kompetensi, Independensi, Time Budget Pressure, dan Audit Fee Terhadap Kualitas Audit Pada KAP Surabaya.

Atiqoh, N., \& Riduwan, A. (2016). Pengaruh Due Professional, Motivasi Auditor, Time Budget Pressure Terhadap Kualitas Audit.

Basuki, \& Mahardani, K. Y. (2006). Pengaruh tekanan Anggaran Waktu terhadap Perilaku Disfungsional Auditor dan Kualitas Audit Pada KAP di Surabaya.

Elfarini, E. C. (2007). Pengaruh Kompetensi dan Indenpendensi Auditor Terhadap Kualitas Audit. Skripsi.

Fensi, R. E., Sondakh, J. J., \& Ilat, V. (2013). Pengaruh Profesionalime Auditor, Kualitas Audit, etika Profesi Auditor dan Pengalaman Auditor Terhadap Pertimbangan Tingkat Materialitas Dalam pemeriksaan Laporan Keuangan Republik Indonesia Perwakilan Sulawesi Utara.

Hutabarat, G. (2012). Pengaruh pengalaman, Time BUdget Pressure, dan Etika Auditor Terhadap Kualitas Audit. 6 No 1. 
Imansari, P. F., Halim, A., \& Wulandari, R. (2016). Pengaruh Kompetensi, Independensi, Pengalaman dan Etika Auditor Terhadap Kualitas Audit.

Inapty, B. (2007). Pengaruh Konflik Biaya dengan Kualitas Audit Terhadap Dysfunctional Behaviour. Tesis.

Indah, S. N. (2010). Pengaruh Kompetensi dan Independensi Auditor terhadap Kualitas Audit. Skripsi.

Kartika, D. (2015). Pengaruh Pengalaman Auditor dan Etika Auditor Terhadap Kualitas Audit.

Muhshyi, A. (2013). Pengaruh Time budget Pressure, Risiko Kesalahan dan Kompleksitas Terhadap Kualitas Audit. Skripsi.

Nataline. (2007). Pengaruh Batasan Audit, Pengetahuan Akuntansi dan Auditing, Bonus serta Pengalaman Terhadap Kualitas Audit Pada Kantor Akuntan Publik di Semarang. Skripsi.

Nirmala, R. P. (2013). Pengaruh Independensi, Pengalaman, Due Professional Care, Akuntabilitas, Kompleksitas Audit, dan Time Budget Pressure terhadap Kualitas Audit. Skripsi.

Sastra, S. P. (2011). Pengaruh Due Professional Care, Kompleksitas Audit dan Tekanan Anggaran Waktu Terhadap Kualitas Audit. Skripsi.

Setyorini, A. I. (2011). Pengaruh Kompleksitas Audit, Tekanan Anggaran Waktu, Dan Pengalaman Auditor Terhadap Kualitas Audit dengan Variabel Moderating Pemahaman Terhadap Sistem Informasi.

Simanjuntak, P. (2008). Pengaruh Time Budget Pressure dan Resiko Kesalahan Terhadap Penurunan Kualitas Audit (Reduced Audit Quality) (Studi Empiris Pada Auditor KAP Jakarta). Thesis.

Tarigan, M. U., Bangun, P., \& Susanti. (2013). Pengaruh Kompetensi, Etika, dan Fee Audit Terhadap Kualitas Audit.

Tjun, L. T., Marpaung, E. I., \& Setiawan, S. (2012). Pengaruh Kompetensi dan Indenpendensi Auditor Terhadap Kualitas Audit. Vol. 4 No. 1 Mei 2012: 33-56 